\title{
Slope stability analyses by circular failure chart and limit equilibrium methods: the inlet and outlet of diversion tunnel of Bolango Ulu Dam, Indonesia
}

\author{
Alesandro Sejo Luden ${ }^{1,2}$, I Gde Budi Indrawan ${ }^{1 *}$, and Dwikorita Karnawati ${ }^{1}$ \\ ${ }^{1}$ Departement of Geological Engineering, Universitas Gadjah Mada, Yogyakarta, Indonesia \\ ${ }^{2}$ Ministry of Public Works and Housing of Indonesia, South Jakarta 12110, Indonesia
}

\begin{abstract}
The objective of this research is to evaluate the stability of the natural slopes at the inlet and outlet portals of the Bolangu Ulu diversion tunnel, Gorontalo. The natural slopes were considered stable, and therefore slope stability analyses were not carried out previously in the tunnel portal design. The slope stability analyses were carried out using the Circular Failure Chart (CFC) and Limit Equilibrium Methods (LEM). Input data for the slope stability analyses were obtained from field mapping and laboratory testing of soil and rock samples. The results show that the portal slopes consist of diorite and residual soil. Both stability analysis methods yield nearly the same results. The slope at the outlet section had the factor of safety (FOS) values of 1.29 and 1.30 based on the CFC method and LEM, respectively, indicating the slope in a stable condition. However, the slope at the inlet section had the FOS values of 1.01 and 1.07 based on the CFC method and LEM, respectively, indicating the slope in a critical condition. The results suggest that stabilization of the portal slopes, particularly the portal slope at the inlet section, is required to prevent slope failures under static and earthquake loads.
\end{abstract}

\section{Introduction}

Slope failures are a serious geo-environmental hazard that endangers human populations, transportation routes such as highways and rail lines, and civil structures such as dams, buildings, and other structures [1]. Predicting and analyzing the slope's stability is a serious challenge for geotechnical engineers [2]. It plays an essential role for a designer to plan engineering structures, namely dams, tunnels, roads, etc. In tunnel construction, slope stability analysis is required to ensure the portal is stable during the construction and operation [3]. It also helps the designer to estimate the construction cost that will be involved. Many researchers focused on assessing and developed various methodologies for slope stability.

Slope stability analysis is performed to assess the safety factor of potential and probable slope failures [4]. The safety factor is comparing shear strength to maintain slope stability and the shear strength that causes. From the comparisons, it is obtained the value of slope stability expressed in numbers. In the condition that Factor of Safety $(\mathrm{FOS})>1$, the slope will be stable. However, if the FOS $<1$, the slope becomes unstable, and slope failures occur [5]. The slope is considered stable when the FOS is greater than one, and the driving shear stress is lower than the resistive shear stress [1]. When this ratio approaches 1 , shear strength and shear stress are approximately equal, and the slope is on the verge of failure or critical condition. If the slopes become unstable, remedial and corrective can be proposed to develop a construction area, namely rock slope stabilization programs [1].

This paper presents the results of stability analyses of natural slopes at the inlet and outlet portals of the Bolango Ulu Dam's diversion tunnel using the Circular Failure Chart and Limit Equilibrium Method. It is expected that the results of this research contribute to the safe designs of the tunnel portal slopes.

\subsection{Study area}

Bolango Ulu Dam is located in Bone Bolango Regency, Gorontalo Province, Indonesia (Figure 1). The inlet and outlet section of the diversion tunnel is considered for the slope stability study.

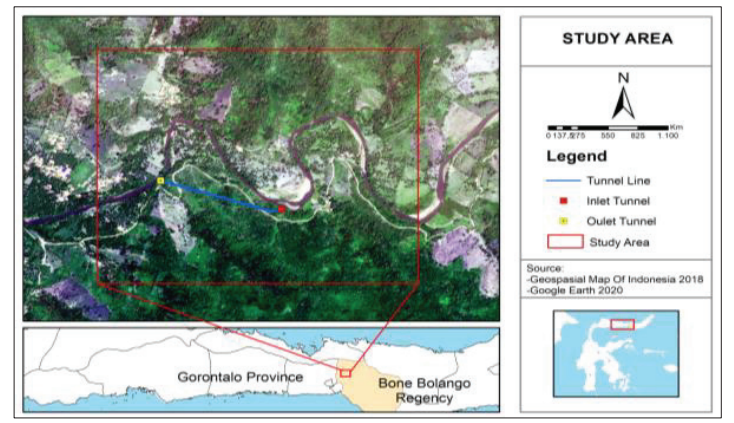

Fig. 1. Location map

\footnotetext{
* Corresponding author: igbindrawan@ugm.ac.id
} 


\section{Methodology}

\subsection{Sample collections and field parameters}

The data used in this study include the geological structure and the slope, geological mapping, core drill, and engineering properties from laboratory test results. Two types of samples were collected for laboratory analysis, namely surface samples and core samples. Surface samples were collected along every section taken up for stability analysis and collected from the subsurface for different sections chosen for analysis. Rock and soil samples were obtained from various areas of the slope profile at each slope segment. The soil samples were taken from a depth of $1.0 \mathrm{~m}$ after removing the overburdened soil, while the rock sample was collected from the drill core.

The collected samples were put through a direct shear test. These representative samples were put through a direct shear test with five different normal loads to obtain their shear strength values. The measurements were plotted in normal stress (x) and shear stress (y) to get representative shear strength parameters. All samples were subjected to direct shear strength testing to get the value of the angle of internal friction $(\varphi)$ and determine cohesion (c), as per the procedure mentioned in ASTM D-2850 directive [6]. The core cutter analysis was used to obtain the bulk density $(\gamma)$ of the soil samples. Core samples were used to obtain the unit weight and density of soil materials and the grain size of soil samples. The slope depth of overburden material and face angle were analyzed and measured through site work.

\subsection{Circular Failure Chart (CFC)}

The circular failure charts are used to find an essential combination of slide surface and tension crack for a wide range of slope geometries and groundwater conditions [5]. The circular Failure Chart method is the easiest method to analyze and find out the Factor of Safety. This method is a semi-empirical approach method and required minimum laboratory testing. Its required parameters are density, shear strength, height, and steepness of the cut slope. These parameters will give the safety factor of the particular slope after plotting the corresponding circular failure chart. Circular failure happens when the small particles in soil or completely exposed rock mass are small compared to the slope's size and are not interlocked due to their shape [7].

In the Circular Failure Chart (CFC), several groundwater flow schemes are given to adjust the pore water pressure in the subsurface and stresses due to water present in tension fractures [1]. For that purpose, Figure 2 depicts a set of possible field conditions that have been chosen and shown in a combined manner [1].

To obtain the FOS, follow the techniques explained below and depicted in Figures 3 and 4 . The first step is to choose rock strength parameters that apply to the slope's material. Then determine the groundwater conditions on the slope and select the chart closest to these conditions using Figure 2. The next step is to compute the dimensionless ratio with the formula below:

$$
\mathrm{c} /(\gamma \mathrm{H} \tan \varphi)
$$

Furthermore, find this value on the chart's outer circular scale. The value found to the junction with the curve corresponds to the slope angle and follows the radial line. The last step is to find the suitable value of $\mathrm{c} /(\mathrm{H} \mathrm{FS})$ or tan/FS, whichever is more convenient and calculate the FOS.

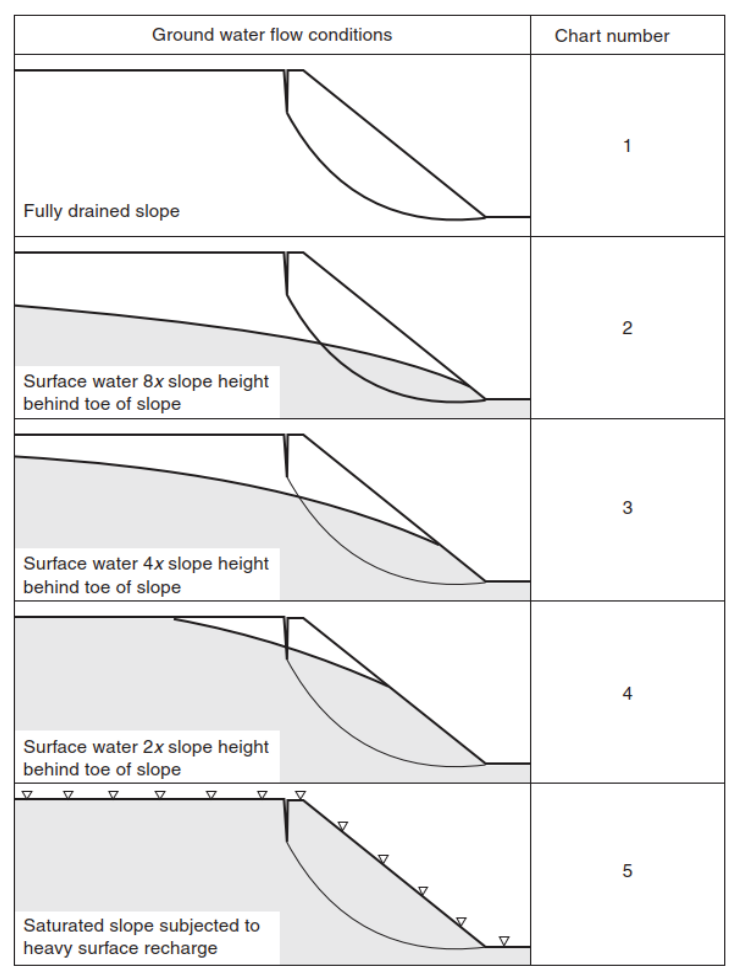

Fig. 2. Groundwater conditions chart [5].

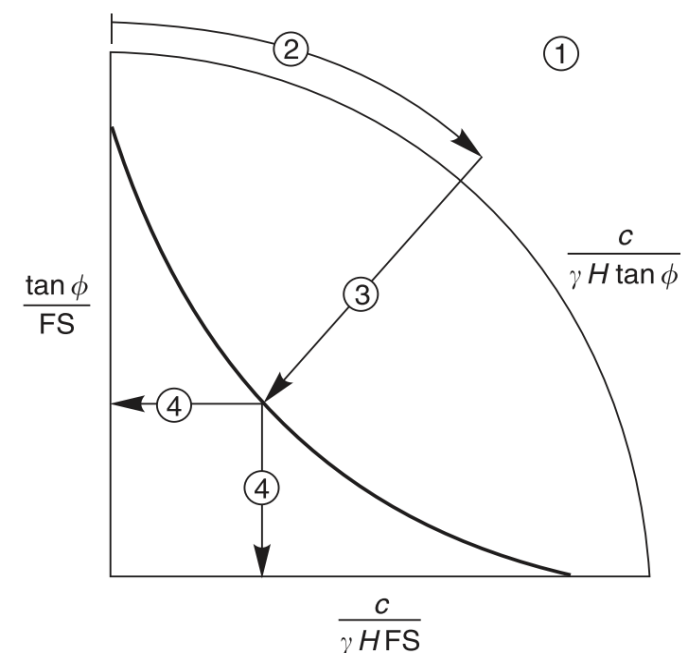

Fig. 3. Calculation of FOS from CFC chart [5]. 


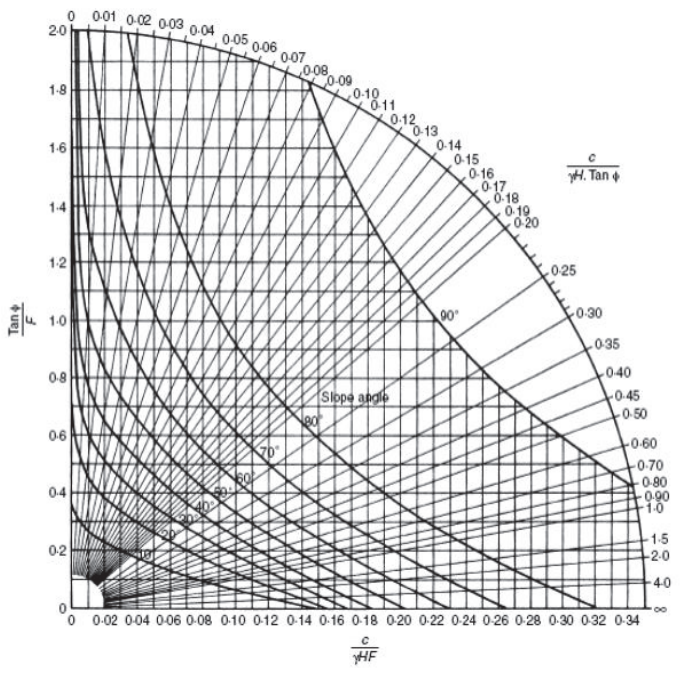

Fig. 4. Model CFC chart [5].

\subsection{Limit Equilibrium Method (LEM)}

LEM is a method that uses the principle of force equilibrium [8]. This analysis method assumes that the area of failure that possibly occurs in circular failure or noncircular failure. The calculation method is divided the landslide plane into slices. Figure 5 shows the forces that are considered on every slice.

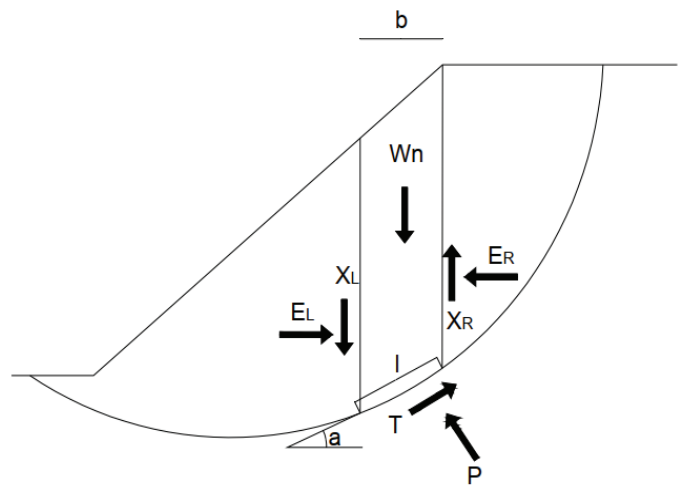

Fig. 5. The forces considered.

LEM analysis was performed using Slide software from Rocscience. Analysis slope stability is carried out using a method developed by Fellenius (the standard method of the slice), Bishop, Janbu, Morgenstern-Price, Spencer, and Sarma $[9,10,11]$. Fellenius introduced the first method in which the forces between the slices are ignored and only considered the moment equilibrium. Bishop [9] then develops more complex ways by incorporating a working force around the wedge plane but calculates with moment equilibrium. Bishop [9] also came up with the Simplified Bishop Method where the force is normal between the slices is considered, but the inter shear force of the slices is ignored. Janbu [10] developed the method which is similar to Bishop's simple method. The difference is that the Janbu [10] method was derived from the horizontal force equilibrium.

\section{Result and discussion}

\subsection{Geological condition}

\subsubsection{Lithology}

The main rock formation consisting of the study area is the diorite and alluvial deposits. Diorite occupies about $85 \%$ of the study area. This unit is exposed along the slopes on the left and right of the Bolango river. This rock unit is grey-brown to grey-white, phaneritic, quartz, and the minerals biotite, andesine, and pyrite. The weathering level is light to strong, and the hardness level is weak to very strong. The soil resulting from weathering of diorite is in the form of clay sand, greyishbrown in colour, medium to coarse-grained, strongly weathered to perfect, relative density decomposed to dense. This diorite unit is equivalent to the Bone Diorite Unit on the Kotamobagu geological map sheet, estimated to be of the late Miocene age [12].

Alluvial unit is found on the left and right from upstream to downstream of the Bulango river and becomes floodplains as water discharge rises. The characteristic is fine to lumps, with a percentage of coarse to fine sand is $30 \%$, gravel about $50 \%, 10 \%$ lumps, and $10 \%$ mud. This unit is characterized by the condition of loose and rounding blocks.

\subsubsection{Geological structure}

The geological structures found in the study area are normal faults and shear joints. Normal faults were found by the presence of slickensides or fault mirrors shaped like smooth planes and striations that seemed to be polished (Figure 6). The normal fault is in the form of a left shear fault (sinistral) with a direction of $\mathrm{N} 35^{\circ} \mathrm{E}$. The direction is unidirectional of the river's bend, where the river's bend can indicate a geological structure. The fault at the study site cuts the dam axle continuously downstream of the inlet of the diversion tunnel. The existence of this geological structure is not expected to have a significant effect on the stability of the tunnel because the existing faults are no longer active.

The joint structure found in the study area generally develops in diorite units, namely shear joints. These shear joints have the characteristics of straight joint planes; sometimes, there is a slight shift, the fracture plane is tight, and the angle of the joint pair that intersects each other is $60^{\circ}$ or more [13].

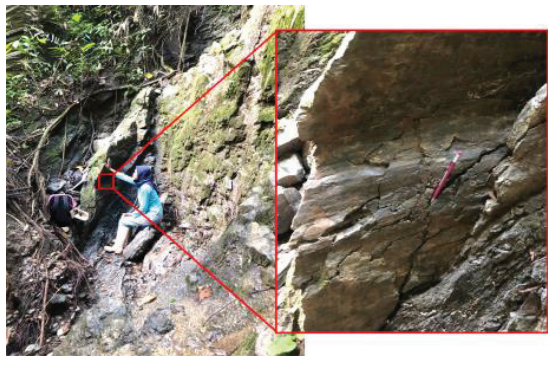

Fig. 6. The presence of slickensides or fault mirrors. 
Based on the lithology and geological structure found during the field work, the geological map of the study area is prepared and shown in Figure 7.

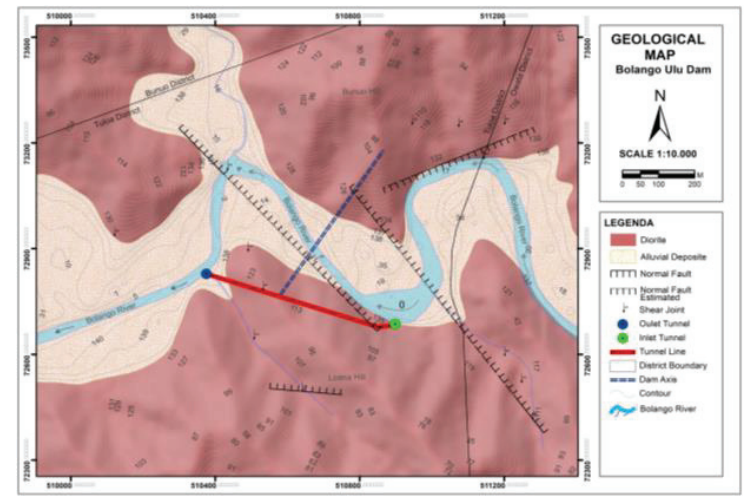

Fig. 7. The geological map of the study area.

\subsection{Estimation of FOS using CFC method}

Four samples in two sections (inlet and outlet tunnel) were chosen for comprehensive stability investigations and FOS evaluation utilizing the CFC method to estimate the factor of safety [7]. The most suitable chart for groundwater conditions and slope geometry in the study area is chart number 2 . Table 1 shown the input parameters used to determine the dimensionless ratio $(c /(\gamma H \tan \varphi))$. The charts for the circular failure method are shown in Figures 9-12. The safety factor at the inlet section is very close to 1 . This condition indicated that these slope sections are at risk of collapsing and failing during heavy rain or when the excavation tunnel begins. This result confirms the presence of slope Failures in the outlet section during the field investigation (Figure 8). The outlet section FOS critical value is 1.18 indicating the slope in favourably stable condition. The critical FOS values of all slope sections at various saturation conditions are given in Table 2. The details of each slope section are discussed below.

\subsubsection{IL - 1 (Residual soil)}

The slope section IL-1 is located at the inlet section of the diversion tunnel. This soil sample was collected from the surface. The height of the slope is about 12.5 $\mathrm{m}$. According to the given observation, the critical factor of safety is 1.01 . This number of safety factors indicates that the slope is in critical condition.

\subsubsection{IL - 2 (Diorite)}

The slope section I-2 is the second sample point in the inlet portal tunnel selected for analysis. This sample is a rock sample collected from the drill core. The inclination of the general slope is about $50^{\circ}$. In all charts, the FOS value is bigger than 1.0 indicates that the slope is stable (Table 2).

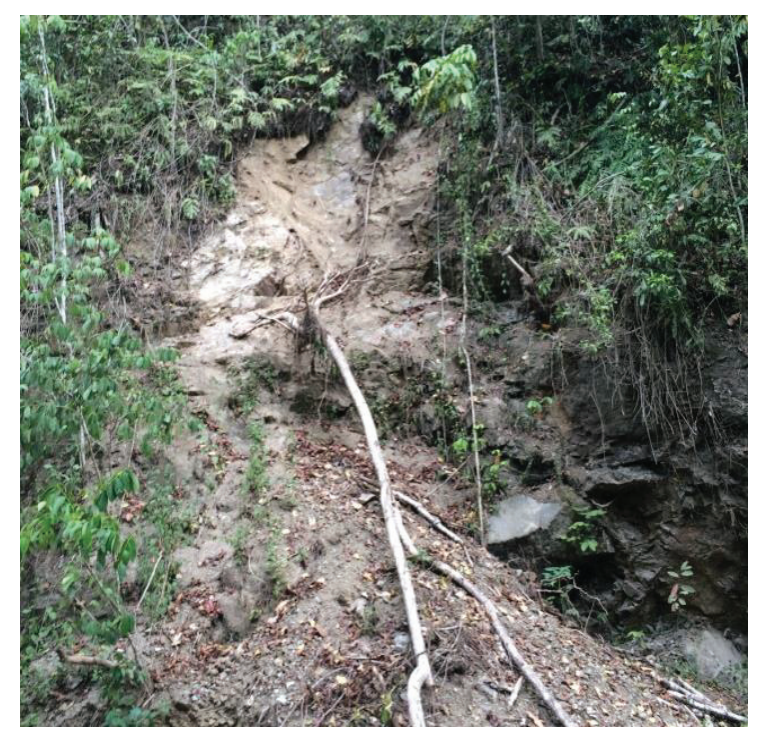

Fig. 8. The Existing slope failure in the study area.

\subsubsection{OL - 1 (Residual soil)}

This slope section is located on the outlet side of the diversion tunnel. It is about $10 \mathrm{~m}$ by height and $45^{\circ}$ in the angle of the slope. The value of cohesion (c) and angle of internal friction $(\varphi)$ are given in table 1 . The factor of safety is calculated in chart number 3 condition. The FOS value is 1.29 indicates the slope is stable.

\subsubsection{OL - 2 (Diorite)}

The last slope section that was carried out for this study is section Outlet 2. This sample is a rock sample collected from the drill core-this section same as section IL-1 located in the outlet section of the diversion tunnel. The parameters are given in table 1 . The result shows that in all charts, the FOS $>1$ indicates the slope is stable. The factor of safety details is given in table 2 .

Table 1. Input parameters for slope stability analysis.

\begin{tabular}{|c|c|c|c|c|c|c|c|}
\hline \multirow[t]{2}{*}{$\begin{array}{l}\text { Slope } \\
\text { Section }\end{array}$} & \multirow[t]{2}{*}{ Layer } & $\begin{array}{c}\text { Slope } \\
\text { height } \\
\text { (H) }\end{array}$ & $\begin{array}{l}\text { Slope face } \\
\text { angle }\end{array}$ & $\begin{array}{c}\text { Unit } \\
\text { weight } \\
(\gamma)\end{array}$ & $\begin{array}{c}\text { Cohesion } \\
\text { (c) }\end{array}$ & $\begin{array}{c}\text { Internal } \\
\text { friction } \\
(\varphi)\end{array}$ & \multirow[t]{2}{*}{$\begin{array}{c}\text { Dimensionless } \\
\text { ratio } \\
(\mathrm{c} /(\gamma \mathrm{H} \tan \varphi)\end{array}$} \\
\hline & & $m$ & Degree & $k N / m 3$ & $k N / m 2$ & Degree & \\
\hline IL- 1 & Residual soil & 12.5 & 50.0 & 17.71 & 20.20 & 20.93 & 0.24 \\
\hline IL- 2 & Diorite & 12.5 & 50.0 & 27.49 & 201.00 & 59.49 & 0.34 \\
\hline OL-1 & Residual Soil & 10.0 & 45.0 & 19.03 & 22.16 & 22.45 & 0.28 \\
\hline OL-2 & Diorite & 10.0 & 45.0 & 28.05 & 226.00 & 62.86 & 0.41 \\
\hline
\end{tabular}


Table 2. FOS values for chart number 2 .

\begin{tabular}{|l|c|l|c|c|}
\hline \multicolumn{2}{|c|}{ Slope Section } & \multicolumn{1}{|c|}{ Layer } & FOS & Critical FOS \\
\hline Inlet & IL-1 & Residual soil & 1.01 & 1.01 \\
\cline { 2 - 5 } & IL-2 & Diorite & 5.39 & 1.29 \\
\hline \multirow{2}{*}{ Outlet } & OL-1 & Residual Soil & 1.29 & \\
\cline { 2 - 5 } & OL-2 & Diorite & 7.36 & \\
\hline
\end{tabular}

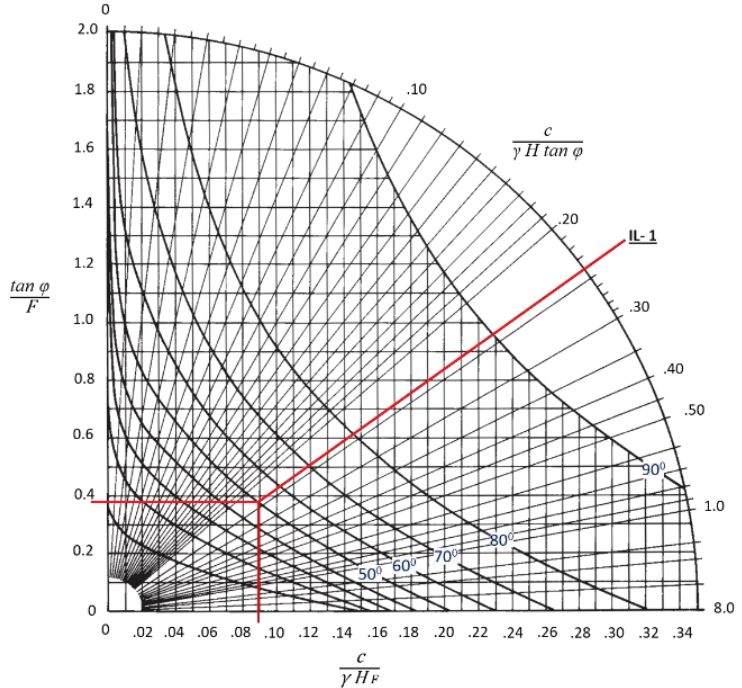

Fig. 9. CFC chart number 2 for slope IL-1.

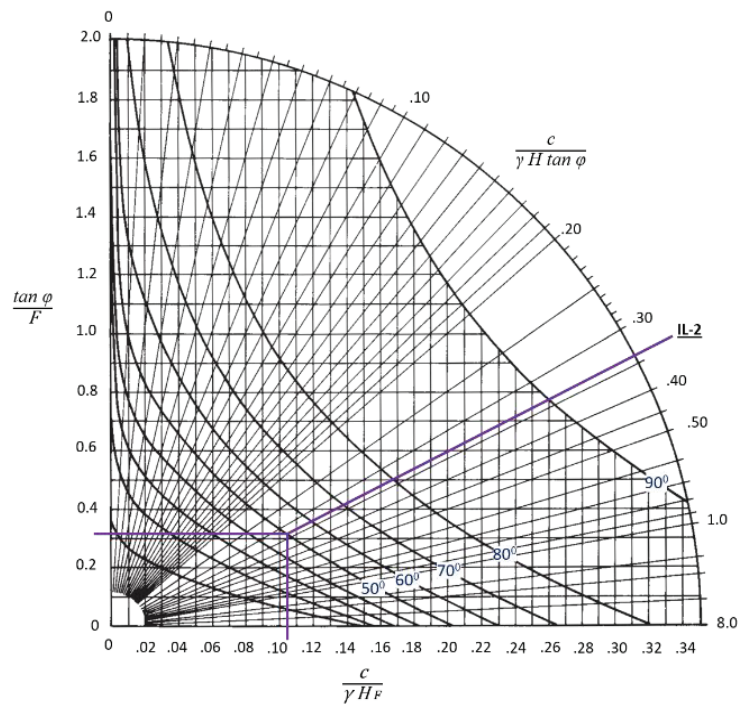

Fig. 10. CFC chart number 2 for slope IL-2.

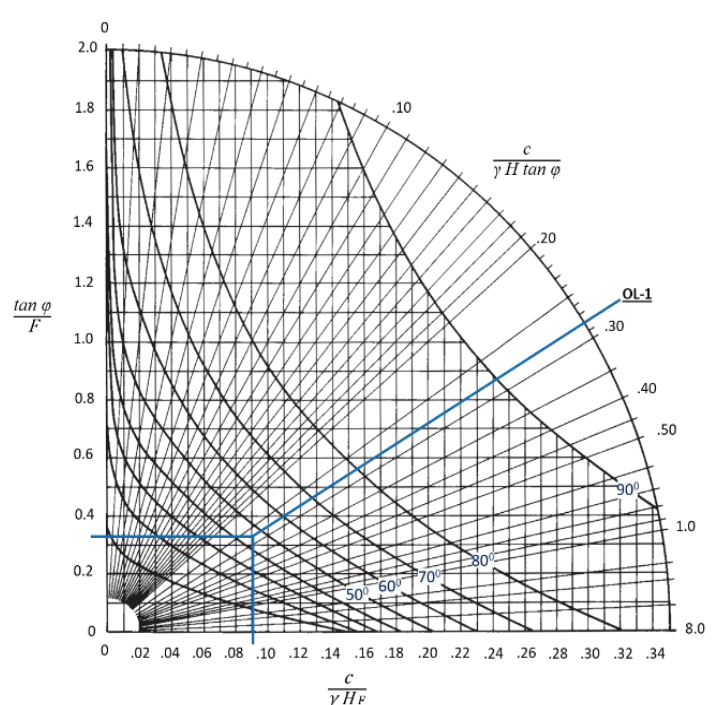

Fig. 11. CFC chart number 2 for slope OL-1.

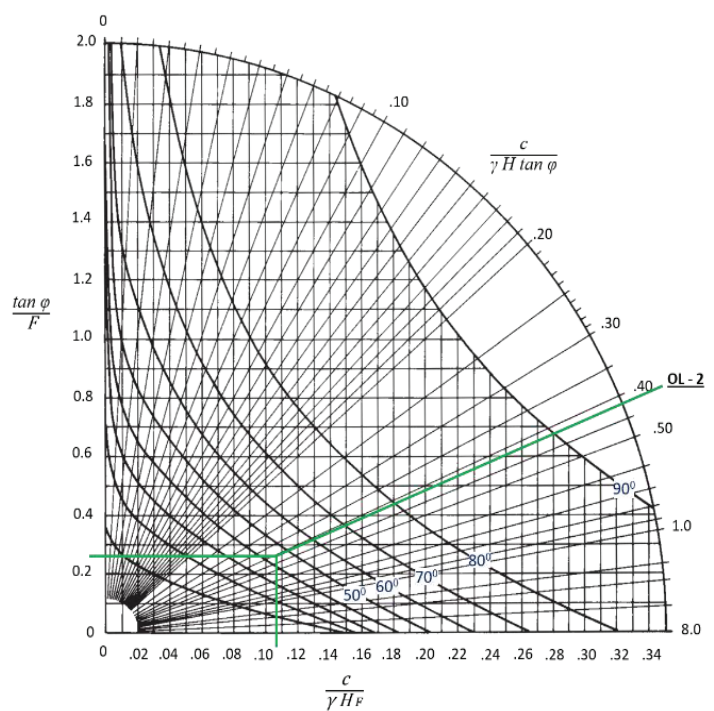

Fig. 12. CFC chart number 2 for slope OL-2. 


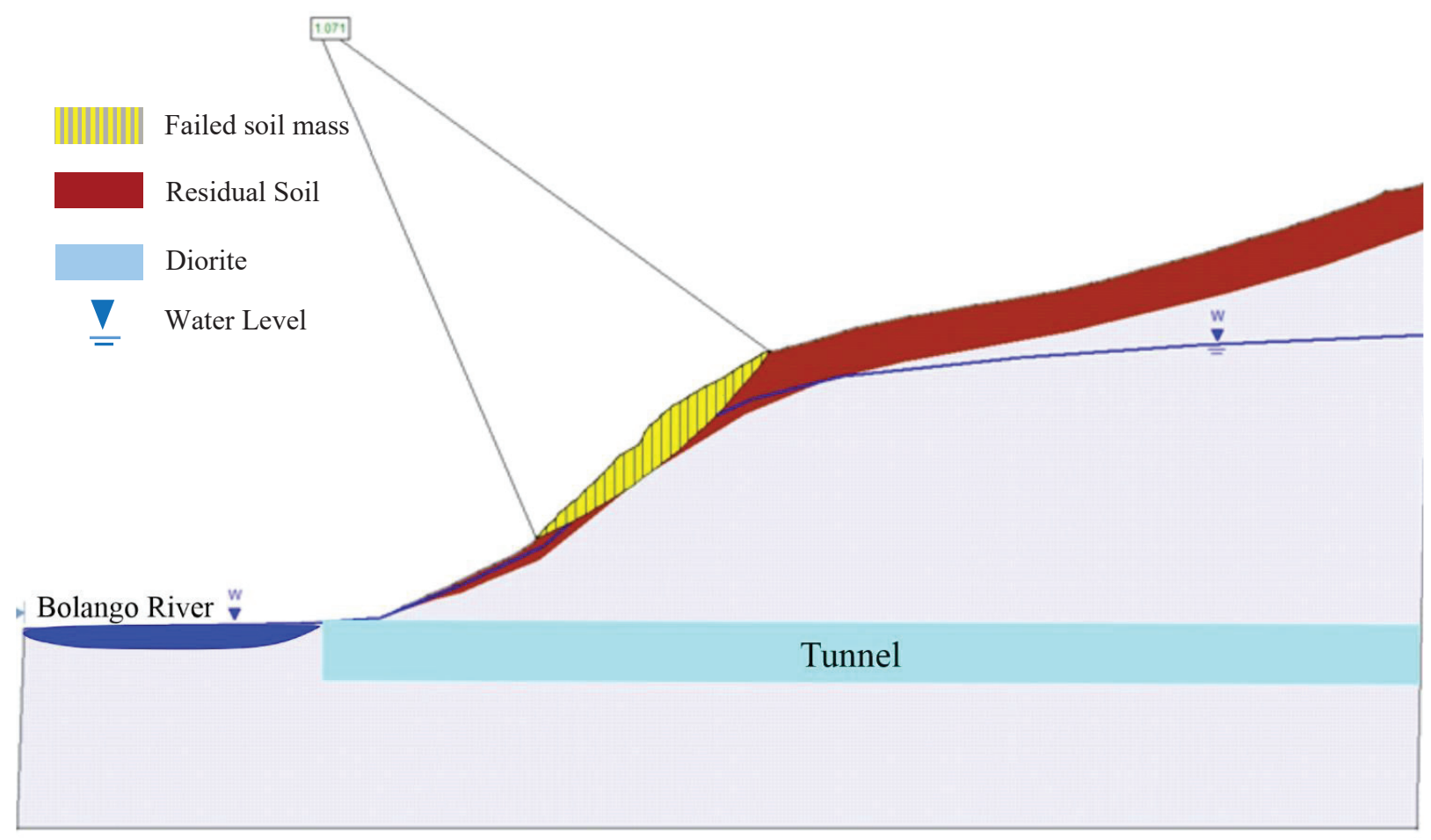

Fig. 13. Slope stability analysis result of inlet section based on LEM.

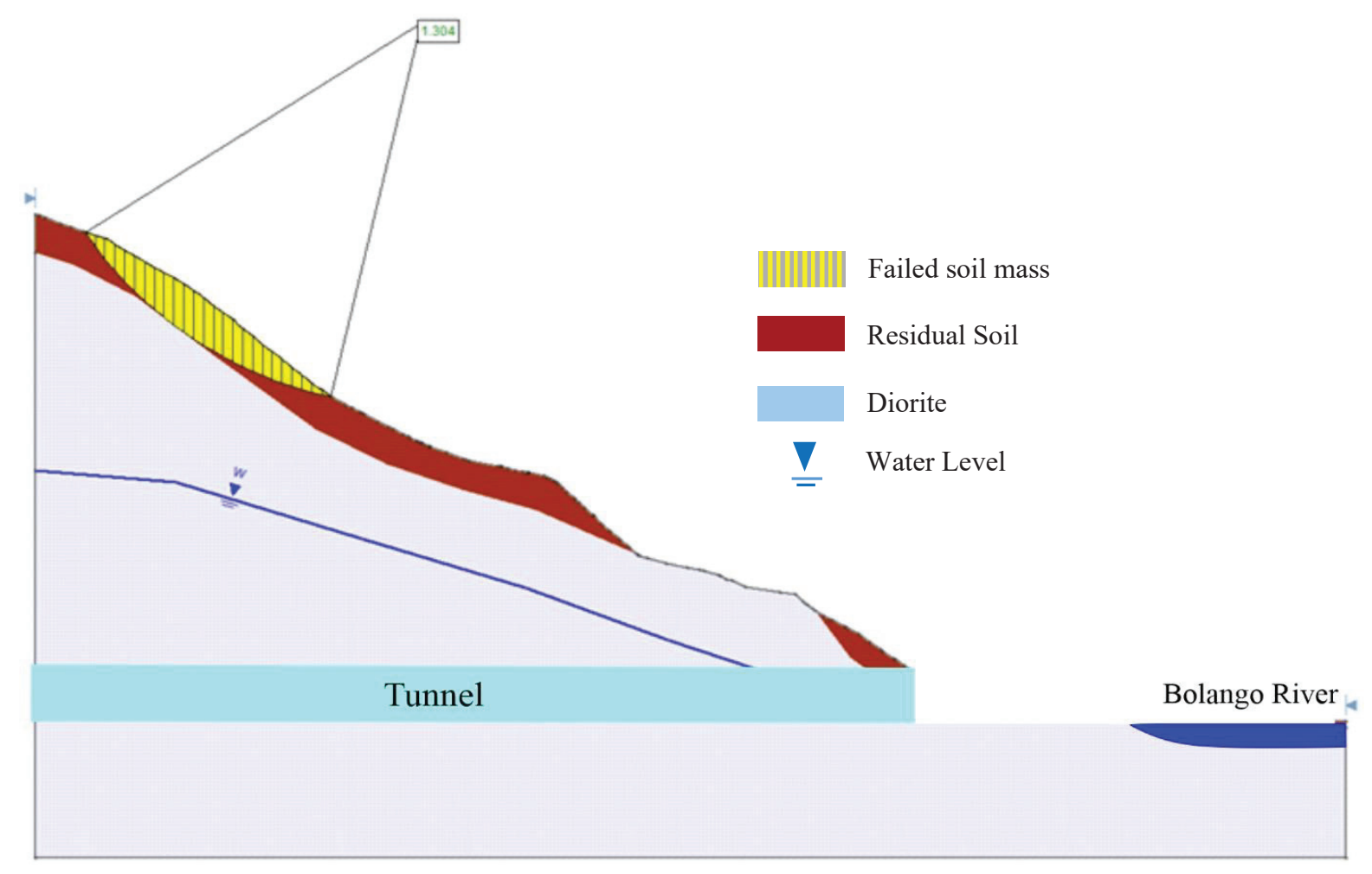

Fig. 14. Slope stability analysis result of outlet section based on LEM. 


\subsection{Estimation of FOS using LEM}

The LEM approach was also used to determine the FOS for each slope section. In each part, both samples (soil and rock) are calculated. Rock and soil properties such as cohesiveness, unit weight, and friction angle of slope forming material were considered. The Factor of Safety values of every slope section using the LEM is shown in Table 3 and Figures 13-14.

Table 3. FOS values for LE method.

\begin{tabular}{|c|c|}
\hline $\begin{array}{c}\text { Slope } \\
\text { Section }\end{array}$ & $\begin{array}{c}\text { FOS } \\
\text { values }\end{array}$ \\
\hline Inlet & 1.07 \\
\hline Outlet & 1.30 \\
\hline
\end{tabular}

The results show that the slope at the outlet section is stable (FOS is more than 1). However, the slope at the inlet section is in critical condition (FOS is close to 1). This result is similar to the Circular Failure Chart Method.

\section{Conclusion and recommendation}

The geological conditions of the research area consist of diorite and alluvial deposits. The diorite occupied $85 \%$ of the research area. There are normal faults and shear joints discovered in the study area. The presence of this geological structure is not expected to have a substantial effect on the stability of the tunnel because the existing faults are no longer active. The unit weight value of the inlet section is $17.71 \mathrm{kN} / \mathrm{m} 3$ for residual soil, and for diorite is $27.49 \mathrm{kN} / \mathrm{m} 3$. The cohesion value of residual soil is $20.2 \mathrm{kN} / \mathrm{m} 2$ and $22.16 \mathrm{kN} / \mathrm{m} 2$ for the inlet and outlet section, while for diorite is $201 \mathrm{kN} / \mathrm{m} 2$ and 206 $\mathrm{kN} / \mathrm{m} 2$. The internal friction of residual soil is $20.93^{\circ}$ and $22.45^{\circ}$ for the inlet and outlet section, while for diorite is $59.49^{\circ}$ and $62.86^{\circ}$.

The Circular Failure Chart and Limit Equilibrium Method produce a similar result. The inlet section of Bolango Ulu's diversion tunnel is nearly unstable because FOS is very close to 1 , while the outlet section is favourably stable. The inlet section requires stabilization before the tunnel excavation to prevent immediate or long-term slope failure. The stabilization measures include decreasing the degree of slope, installing soil nailing and retaining walls, or applying shotcrete. However, further study is required to verify the stabilization measures.

The first author would like to thank the Ministry of Public Works and Housing Indonesia for the research funding and the River Basin Organization of Sulawesi II for allowing this research.

\section{References}

1. M. Kannan, R.R. Rao, S.M. Ahmed, Int. J. Eng. Res. Tech. 7(1) (2019)

2. A. J. Li, R.S. Merifield, A. V. Lyamin, Int. J. Rock Mech. Min. Sci. 45 (2008)

3. R. Yang, P. Guan, K. Cai, W. Xiao, X. Si, Z. Zhaofeng, J. Eng. Sci. Technol. 8, 14-20 (2015)

4. R.R. Djunaedi. Jurnal Student Teknik Sipil 1, 2:55-64 (2020)

5. D.C. Wyllie, C.W. Mah, Rock slope engineering: Civil and mining, 4th edition (Spon Press, New York, 2017)

6. ASTM D2850 - 95, ASTM Int. 15, 1-6 (2015)

7. S. Anbazhagan, V. Ramesh, S.E. Saranaathan, Nat. Hazards 86, 3, 1081-104 (2017)

8. D. Juven, G. Herman, Analisa Stabilitas Lereng Dengan Limit Equilibrium dan Finite Element Method (2016)

9. A.W Bishop, Géotechnique 5, 1, 7-17 (1955)

10. N. Janbu, Int. J. Rock Mech. Min. Sci. Geomech. Abstr. 12, (1975)

11. E. Spencer, Géotechnique 17, 1, 11-26 (1967)

12. T. Apandi, S. Bahri, Peta geologi skala 1:250.000 lembar Kotamobagu (1997)

13. K. McClay, The Mapping of Geological Structures (John Wiley \& Sons, New York, 1988) 